\title{
Effect of Pulse Electric Field on Water Characteristics as a Disinfection Function in Filtration Unit
}

\author{
Ghassan Abukhanafer ${ }^{a^{*}}$, Alaa H. Al-Fatlawi ${ }^{\text {(b) }}{ }^{\text {, Hassan H. Joni }}{ }^{\text {c }}$ \\ ${ }^{a}$ Sanitary and Environmental Engineering, Dept. of Civil Engineering, University of Technology, Iraq. \\ engghassanmoh@gmail.com \\ ${ }^{\mathrm{b}}$ College of Engineering, Environmental Engineering Department, University Babylon, , Iraq. \\ eng.alaa.husaeen@uobabylon.edu.iq \\ ${ }^{c}$ Department of Civil Engineering, University of Technology, Iraq. \\ 40317@uotechnology.edu.iq \\ *Corresponding author.
}

Submitted: 07/03/2020 Accepted: 09/09/2020

Published: 25/01/2021

K E Y W O R D S

Filtration unit, Escherichia coli, pulse electric field, water characteristic.

\begin{abstract}
A B S T R A C T
This paper studied the impact of the addition of pulse electric-filed low voltage (PEF-LV) in the filtration process by designing, constructing, and operating a pilot-scale. The Disinfectant process (DP) demonstrated several benefits in terms of efficiency and ease of application, without the use of any chemical additive. This system contains two pairs of silver mesh electrodes inside the filtration column test with a low pulse voltage for killing microorganisms. The parametric effects of DP performance, such as alternating current pulse frequency and the voltage applied were investigated. The effect of PEF-LV on the biological, physical, and chemical characteristic of water was studied. The transmission electron microscopy (TEM) was used to examine the change of the cell wall morphology of Escherichia coli, Staphylococcus aureus cells for influent, and treated water. The results show the removal efficiency of E. coli and S. aureus $96 \%$ at $30 \mathrm{~V}$ and $0.5 \mathrm{~Hz}$.
\end{abstract}

How to cite this article: G. Abukhanafer, A. H Al-Fatlawi, and H. H. Joni, "Effect of pulse electric field on water characteristics as a disinfection function in filtration unit," Engineering and Technology Journal, Vol. 39, Part A, No. 01, pp. 116-122, 2021.

DOI: https://doi.org/10.30684/etj.v39i1A.1632

This is an open access article under the CC BY 4.0 license http://creativecommons.org/licenses/by/4.0

\section{INTRODUCTION}

Today, the world is facing challenges in meeting increasing demands of drinking water as the available supplies of freshwater are exhausting due to lack of rain, population growth, and more stringent health-based regulations [1-3]. Clean water is vital to human health; the presence of specific bacteria in drinking water is an indicator of its contamination. Insufficient treatment, crosscontamination, and poor maintenance of the distribution network are all common causes of fecal 
contamination of drinking water [4-6]. The assessment of fecal contamination of drinking water relies on indicator bacteria such as coliforms, Escherichia coli, Shigella, Salmonella, Vibrio, and Protozoa (Cryptosporidium) which leads to the spreads of diseases such as giardiasis, cholera, cryptosporidiosis, gastroenteritis, etc., [7,8].

The inactivation and removal of microorganisms are the last steps in the treatment of drinking water. Various disinfection technologies are classified into chemical and physical processes, including chlorine, ozone, chlorine dioxide, and ultraviolet (UV) radiation [9].

Researches in the past decades have shown a problem between effective disinfection and the formation of harmful disinfection byproducts (DBPs). When chlorine comes in contact with natural organic matter (NOM), carcinogenic compounds such as trihalomethanes (THMs) and haloacetic acids (HAAs) can be formed [10,11]. Chemical disinfectants commonly used by the water industry such as free chlorine, chloramines, and ozone can react with natural organics in the water to form DBPs, many of which are carcinogens [12]. The ideal disinfectant must exhibit the following properties: Broad antimicrobial ability at ambient temperature within a short time. It should not generate any harmful by-products during and after its use. Easily applicable and inexpensive for the intended use. Highly soluble in water, easy to store, must not be corrosive for any equipment or surface, and amenable to safe disposal. It is, necessary to search for more safe techniques to kill microorganisms as well as to reduce the dose of chemical additives, decreasing the cost of chemicals avoiding byproduct formation, and residual toxicity of the effluent [13]. The application of the electric field on particle removal is widely applied in the air-particle systems such as electrostatic precipitators (ESPs). nevertheless, in the liquid-particle system, this system has received much less attention, probably because of the limitation in applying a different range of voltage in the water media as well as the higher viscosity of water $[14,15]$. This study investigated pilot-scale using PEF$\mathrm{LV}$ as a disinfection function in the filtration unit for drinking water.

\section{MATERials AND MethodS}

\section{Materials}

The materials used in DP comprises two parts (i) the experimental setup, and (ii) the experimental laboratory. The first and second part was done at the University of Technology laboratory/ Baghdad and laboratory of the ministry of science and technology/environmental research/food contamination, Table 1 clarified these parts.

\section{Method}

A pilot-scale of the DP was designed and constructed to simulate the disinfection processes in the filtration unit (rapid sand filter). A water tank of $500 \mathrm{~L}$ was set beside the unit and used as the reservoir. The influent flow rate was controlled by the flow meter between the water tank and the pipe test. The influent water was raw water from Al Hilla river. The influent water was passed through sand media and disinfected through the pipe test between two pair mesh electrodes by pulse electrical field. The mesh electrodes were alternatively connected to the positive and negative output of the power supply. Voltage change control (0-30 V) was used for controlling the applied voltage along with a pulsed electric device with a different mode of frequency.

The mechanisms of DP illustrate as follows i) the PEF-LV works holes then ruptures the external wall of the microbial cell, leading to the leakage of the inner contents and resulting in the death of the microorganisms. The cells of microorganisms are destroyed, resulting in the reduction of the growth and reproduction of the microbes contributing to the infection and, ii) the water effluent for the experiments period of eight months (Dec. 2018 - July 2019) was tested. (Figure.1) was shown mechanisms of DU. 
TABLE I: The materials that utilized in the experimental setup and experimental laboratory.

\begin{tabular}{|c|c|}
\hline \multicolumn{2}{|c|}{ Materials in the experimental setup } \\
\hline silver mesh & $\begin{array}{c}\text { wires (electrode) } 1.35 \mathrm{~m} \text { length/unit made of pure silver } \\
\text { with } 99 \% \text { purity. }\end{array}$ \\
\hline pipe test & $\begin{array}{c}\text { polyvinyl chloride (PVC) diameter of } 0.15 \mathrm{~m} \text {, length } 2 \mathrm{~m} \text {, a } \\
\text { cross-section area } 0.0176 \mathrm{~m}^{2} .\end{array}$ \\
\hline filter media & Conventional filtration (local sand and support gravel) [27] \\
\hline Adapter power & voltage change regulator model 001 \\
\hline pulse frequency device & model (kb-sk07) measure the number of pulse per second. \\
\hline power supply & Alternating current $\mathrm{AC}$ \\
\hline inlet and outlet pipe & PVC diameters of 0.0125 and $0.0375 \mathrm{~m}$, \\
\hline influent water & water from filtration process \\
\hline water tank & 500 L stainless-steel \\
\hline flow meter & $(0.25-4 \mathrm{Lpm})$ \\
\hline water pump & $\begin{array}{c}\text { Flow rate } 10-30 \mathrm{~L} / \mathrm{min} \text {, head } 4-30 \mathrm{~m} \text {, the maximum liquid } \\
\text { temperature } 40 \pm 1^{\circ} \mathrm{C} .\end{array}$ \\
\hline \multicolumn{2}{|c|}{ Materials in experimental laboratory } \\
\hline E. coli and S. aureus cells & $\begin{array}{c}\text { MacConkey agar plate and Urinary Tract Infections (UTIs) } \\
\text { media }\end{array}$ \\
\hline Temperature $\left({ }^{\circ} \mathrm{C}\right)$ & Digital Pen Thermometer \\
\hline pH & $\mathrm{pH}$ meter (HI 110 series) \\
\hline Electrical Conductivity Ec. ( $\mu \mathrm{mohs} / \mathrm{cm})$ & C270 Conductivity \\
\hline Alkalinity As $\left(\mathrm{caco}_{3}\right)$ (mg/l) & Phenolphthalein reagent \\
\hline Hardness As $\left(\mathrm{caco}_{3}\right)(\mathrm{mg} / \mathrm{l})$ & titration with EDTA (ethylenediaminetetraacetate acid) \\
\hline Cl. (mg/l) & titration with a silver nitrate solution \\
\hline $\mathrm{Ca}(\mathrm{mg} / \mathrm{l})$ & titration with EDTA (ethylenediaminetetraacetate acid) \\
\hline $\operatorname{Mg}(\mathrm{mg} / \mathrm{l})$ & titration with EDTA (ethylenediaminetetraacetate acid) \\
\hline
\end{tabular}

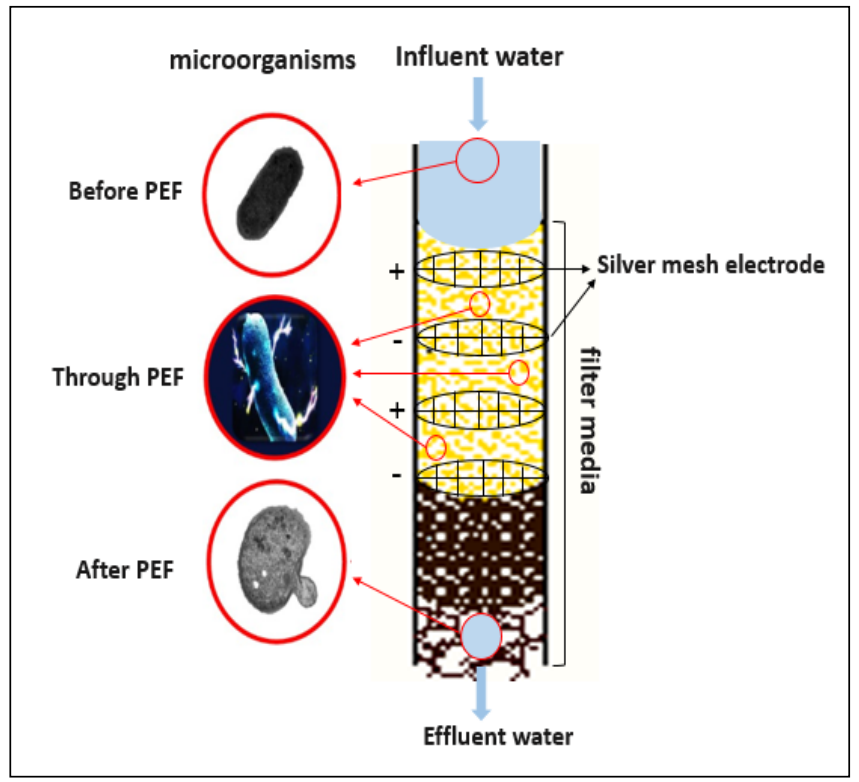

Figure 1: Mechanisms of Disinfectant process between sand media.

\section{RESUltS AND DisCUSSION}

In this paper, several parameters such as i) the effect of applied voltage and AC pulse frequency were investigated. ii) the biological, physical, and chemical characteristics of water before and after the disinfection process were tested. 


\section{Effect of applied voltage and alternating current $(A C)$ pulse frequency}

The pressure from an electrical circuit power source that pushes charged electrons (current) through a conducting loop is called voltage and it is measured in volts $(\mathrm{V})$. While the number of pulse per second in an $\mathrm{AC}$ sine wave is known as $\mathrm{AC}$ frequency. It is the rate at which the current changes the direction in a second, and it is measured in hertz (Hz) [16]. The applied voltage and AC play an important role in DU performance, as it is the main contributing factors to the applied electric field strength [17, 18]. The effect of pulse frequency changing from $0.5,1$ and $2 \mathrm{~Hz}$ to DP performance at different applied voltages $(0-30 \mathrm{~V})$ with a two pair of silver electrode mesh were tested. At these frequencies, the corresponding exposure time was 2,1 , and 0.5 seconds respectively. Therefore, $0.5 \mathrm{~Hz}$ was selected as the optimal frequency because the amount of time for which a bacteria cell was exposed increased according to Planck's formula (Eq. 1) [19]. Due to giving high removal efficiency of E. coli and S. aureus.

$$
\text { Frequency }=\frac{1}{\text { Time }(s)}
$$

Increasing the applied voltage to $30 \mathrm{~V}$ at $0.5 \mathrm{~Hz}$ yielded better removal efficiencies of E. coli and $\mathrm{S}$. aureus. The results of disinfection were approximately the same value $96 \%$. These results are consistent with researchers [20-22]. Figure 2 demonstrates that the relationship between applied voltage and AC with removal efficiency.

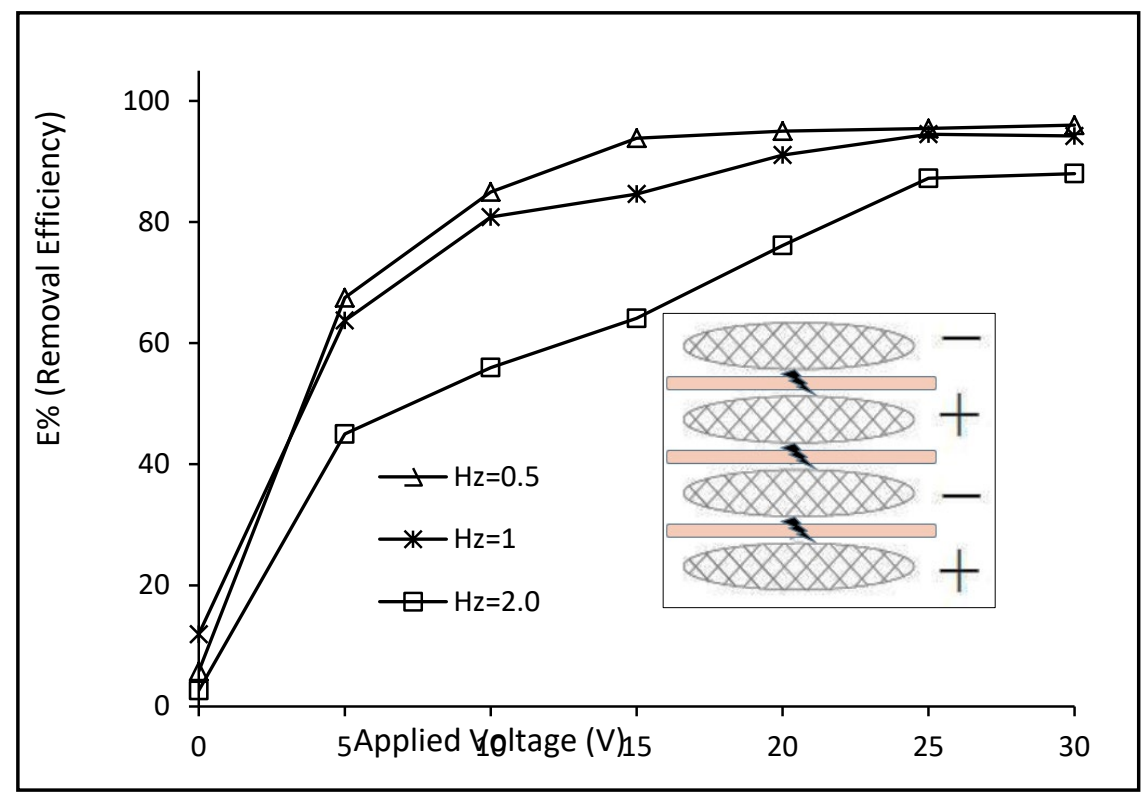

Figure 2: the effect of applied voltage and AC pulse frequency on the removal efficiencies of E-coli and $\mathrm{S}$. aureus meshes electrodes.

\section{Characteristics of water}

\section{A. Biological test}

This paper used transmission electron microscopy TEM to show the status of microorganisms before and after the disinfection process. Figure 3 and 4 illustrate micrographs of E. coli and S. aureus, the change in the cell wall morphology in the influent water (it was a normal cell shape with an undamaged structure of inner and intact outer membrane) and that in effluent water was peptide-induced breakage and roughness in the cell wall. Increasing damage to the microorganism cell wall was evident in the form of cracks developed by the rising voltage to $30 \mathrm{~V}$. Cell shrinkage due to the loss of turgor was also noted. 


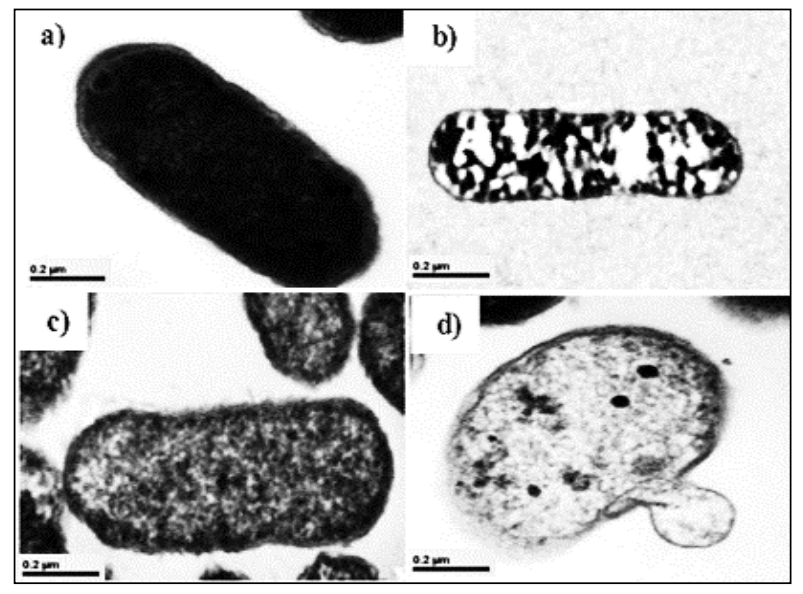

Figure 3: TEM micrograph of E. coli (a) untreated cell, (b and c) treated cell under 10-20V (d) rupture the cell wall under $30 \mathrm{~V}$.

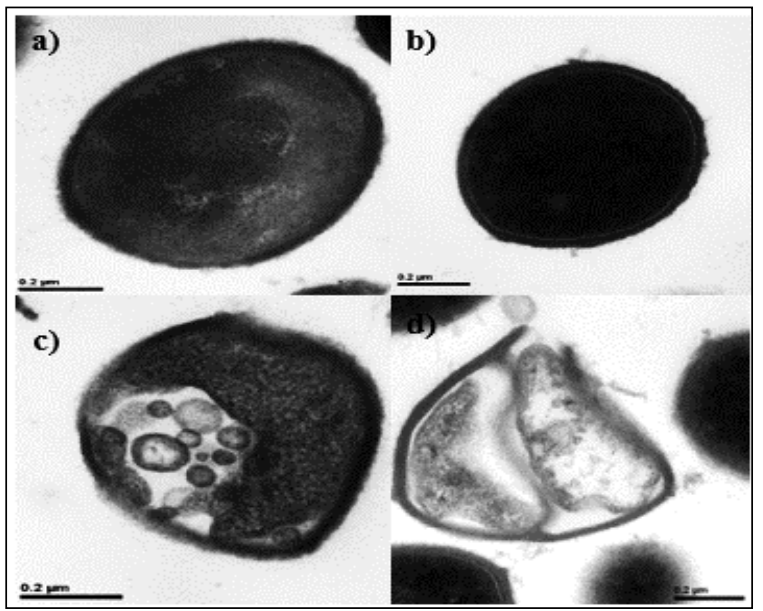

Figure 4: TEM photographs of $S$. aureus cells (a) untreated cell, (b and c) treated cell under 10-20V (d) rupture the cell wall under $30 \mathrm{~V}$.

B. Physical and chemical characteristics test

PEF-LV has a slight effect on the physical and chemical parameters of influent and effluent water. Temperature, $\mathrm{pH}$, electrical conductivity, alkalinity, chloride, calcium, magnesium, and hardness were investigated. All results of the physical and chemical tests were within the Iraqi standard limits of drinking water (Table 2 and 3 ).

TABLE II: Physical characteristics for influent and effluent water.

\begin{tabular}{|c|c|c|c|c|c|c|c|}
\hline \multirow{2}{*}{$\begin{array}{l}\text { physical } \\
\text { parameter }\end{array}$} & \multirow[t]{2}{*}{ month } & \multicolumn{2}{|c|}{ Samples } & \multirow[t]{2}{*}{ Month } & \multicolumn{2}{|c|}{ Samples } & \multirow{2}{*}{$\begin{array}{c}\text { Iraqi Standard } \\
{[23-26]}\end{array}$} \\
\hline & & $\begin{array}{c}0 V \\
\text { influent }\end{array}$ & $\begin{array}{c}30 \mathrm{~V} \\
\text { effluent }\end{array}$ & & $\begin{array}{c}0 V \\
\text { influent }\end{array}$ & $\begin{array}{c}30 \mathrm{~V} \\
\text { effluent }\end{array}$ & \\
\hline \multirow{4}{*}{$\begin{array}{c}\text { Temperature } \\
\left({ }^{\circ} \mathrm{C}\right)\end{array}$} & Dec. & 16.3 & 16.9 & Apr. & 22.0 & 21.5 & 25 \\
\hline & Jan. & 13.6 & 14.0 & May & 25.3 & 25.7 & \\
\hline & Feb. & 15.0 & 14.8 & Jun. & 30.0 & 30.0 & \\
\hline & Mar. & 18.3 & 18.1 & Jul. & 33.0 & 32.4 & \\
\hline \multirow[t]{4}{*}{ pH } & Dec. & 7.9 & 8.1 & Apr. & 8.0 & 8.0 & $6.5-8.5$ \\
\hline & Jan. & 7.9 & 7.9 & May & 7.8 & 7.5 & \\
\hline & Feb. & 7.9 & 8.0 & Jun. & 7.7 & 7.6 & \\
\hline & Mar. & 7.2 & 7.5 & Jul. & 8.0 & 7.8 & \\
\hline \multirow{4}{*}{$\begin{array}{c}\text { Electrical } \\
\text { Conductivity } \\
\text { Ec. } \\
(\mu \mathrm{mohs} / \mathrm{cm})\end{array}$} & Dec. & 1387 & 1380 & Apr. & 1539 & 1541 & 2000 \\
\hline & Jan. & 1556 & 1551 & May & 1269 & 1271 & \\
\hline & Feb. & 1287 & 1290 & Jun. & 870 & 872 & \\
\hline & Mar. & 1671 & 1673 & Jul. & 824 & 820 & \\
\hline
\end{tabular}


TABLE III: Chemical characteristics for influent and effluent water

\begin{tabular}{|c|c|c|c|c|c|c|c|}
\hline \multirow{2}{*}{$\begin{array}{l}\text { chemical } \\
\text { parameter }\end{array}$} & \multirow[t]{2}{*}{ month } & \multicolumn{2}{|c|}{ Sample } & \multirow[t]{2}{*}{ Month } & \multicolumn{2}{|c|}{ Sample } & \multirow{2}{*}{$\begin{array}{c}\text { Iraqi Standard } \\
{[23-26]}\end{array}$} \\
\hline & & $0 \mathrm{~V}$ & $30 \mathrm{~V}$ & & $0 \mathrm{~V}$ & $30 \mathrm{~V}$ & \\
\hline \multirow{4}{*}{$\begin{array}{c}\text { Alkalinity } \\
\text { As (caco }) \\
(\mathrm{mg} / \mathrm{l})\end{array}$} & Dec. & 130 & 127 & Apr. & 120 & 117 & 200 \\
\hline & Jan. & 136 & 130 & May & 120 & 115 & \\
\hline & Feb. & 145 & 142 & Jun. & 120 & 119 & \\
\hline & Mar. & 126 & 120 & Jul. & 114 & 116 & \\
\hline \multirow{4}{*}{$\underset{(\mathrm{mg} / \mathrm{l})}{\mathrm{Cl}}$} & Dec. & 116 & 117 & Apr. & 104 & 102 & 350 \\
\hline & Jan. & 122 & 120 & May & 79 & 80 & \\
\hline & Feb. & 107 & 112 & Jun. & 71 & 70 & \\
\hline & Mar. & 125 & 122 & Jul. & 70 & 68 & \\
\hline \multirow{4}{*}{$\underset{(\mathrm{mg} / \mathrm{l})}{\mathrm{Ca}}$} & Dec. & 75 & 80 & Apr. & 75 & 78 & 150 \\
\hline & Jan. & 98 & 100 & May & 64 & 70 & \\
\hline & Feb. & 108 & 114 & Jun. & 83 & 85 & \\
\hline & Mar. & 118 & 120 & Jul. & 67 & 70 & \\
\hline \multirow{4}{*}{$\underset{(\mathrm{mg} / \mathrm{l})}{\mathrm{Mg}}$} & Dec. & 45 & 43 & Apr. & 29 & 30 & 100 \\
\hline & Jan. & 35 & 37 & May & 34 & 37 & \\
\hline & Feb. & 33 & 34 & Jun. & 55 & 60 & \\
\hline & Mar. & 43 & 45 & Jul. & 39 & 40 & \\
\hline \multirow{4}{*}{$\begin{array}{c}\text { Hardness } \\
\text { As (caco }) \\
(\mathbf{m g} / \mathbf{l})\end{array}$} & Dec. & 405 & 410 & Apr. & 432 & 440 & 500 \\
\hline & Jan. & 426 & 430 & May & 407 & 420 & \\
\hline & Feb. & 444 & 445 & Jun. & 320 & 325 & \\
\hline & Mar. & 486 & 488 & Jul. & 317 & 333 & \\
\hline
\end{tabular}

\section{CONCLUSION}

Water quality is distinct from the physical, chemical, and biological characteristics of water. Although disinfection or inactivation of microorganisms in conventional methods gives acceptance removal efficiencies, these methods have side effects, especially if combined with organic or other materials, while the method of PEF-LV was used and gave high removal efficiencies without adding any chemicals and no change in the water quality. This paper represents a safer disinfectant unit (DU), the pilot-scale utilized two pair silver electrode mesh with a low voltage for disinfectant function. DU was affected by AC pulse frequency and the applied voltage. The biological, physical and chemical characteristics for influent and effluent water were examined. Removal efficiencies of E. coli and S. aureus cells at $0.5 \mathrm{~Hz}$ and $30 \mathrm{~V}$ was $96 \%$. The physical and chemical tests for effluent water were within the Iraqi standard limits of drinking water

\section{ACKNOWLEDGMENTS}

The authors would like to thank the Environmental College of Engineering, University of Technology civil engineering - sanitary and environmental engineering.

\section{REFERENCES}

[1] C. Zhang, et al., Progress and challenges in photocatalytic disinfection of waterborne viruses: a review to fill current knowledge gaps, Chem. Eng., 355(2019) 399-415. https://doi.org/10.1016/j.cej.2018.08.158

[2] A.H. Al-Fatlawi, G. Abukhanafer, and A.A. Salman, Removal of Nitrate from Contaminated Groundwater Using Solar Membrane Distillation, Eng. Technol. J., 37(2019) 327-332. https://doi.org/10.30684/etj.37.3C.4

[3] A. Rus, V.-D. Leordean, and P. Berce. Silver Nanoparticles (AgNP) impregnated filters in drinking water disinfection, MATEC. Web. Conf., 2017 https://doi.org/10.1051/matecconf/201713707007

[4] C. Zhang, et al., Graphitic carbon nitride (g-C3N4)-based photocatalysts for water disinfection and microbial control: a review, Chemosphere, 214(2019) 462-479. https://doi.org/10.1016/j.chemosphere.2018.09.137

[5] H.H.M. Ali and S.T. Ahmed ,Physical and Chemical Characteristics Comparison of the Drinking Water and Water Produced from the Conventional and Modification Solar Water Distillery, Eng. Technol. J., 37(2019)214-221. https://doi.org/10.30684/etj.37.6A.5 
[6] O.H. Kareem, A.H.M. Alobaidy, and R.H. Alanbari, Improving the Properties of Main Drainage Water by Using of Magnetic Field Technique. Eng. Technol. J., 37(2019) 195-200. https://doi.org/10.30684/etj.37.6A.2

[7] K. Khan, et al., Prevalent fecal contamination in drinking water resources and potential health risks in Swat, Pakistan. J. Environ. Sci., 72(2018) 1-12. https://doi.org/10.1016/j.jes.2017.12.008

[8] B. Malla, , et al., Identification of human and animal fecal contamination in drinking water sources in the Kathmandu Valley, Nepal, using host-associated Bacteroidales quantitative PCR assays. Water, 10(2018) 1796. https://doi.org/10.3390/w10121796

[9] K. Song, M. Mohseni, and F. Taghipour, Application of ultraviolet light-emitting diodes (UV-LEDs) for water disinfection: A review, Water. Res., 94(2016)341-349. https://doi.org/10.1016/j.watres.2016.03.003

[10] Li, X.-F. and W.A .Mitch, Drinking water disinfection byproducts (DBPs) and human health effects: multidisciplinary challenges and opportunities, ACS Publications, 2018. https://doi.org/10.1021/acs.est.7b05440

[11] Liu, C., et al., Rapid water disinfection using vertically aligned MoS 2 nanofilms and visible light Nature nanotechnology,11(2016)1098. https://doi.org/10.1038/nnano.2016.138

[12] H. Calvo, et al., Efficacy of electrolyzed water, chlorine dioxide and photocatalysis for disinfection and removal of pesticide residues from stone fruit, Postharvest. Biol. Technol., 148(2019) 22-31. https://doi.org/10.1016/j.postharvbio.2018.10.009

[13] Du, Y., et al., Formation and control of disinfection byproducts and toxicity during reclaimed water chlorination: A review, J. Environ. Sci., 58(2017)51-63. https://doi.org/10.1016/j.jes.2017.01.013

[14] M.C. Collivignarelli, et al., Overview of the main disinfection processes for wastewater and drinking water treatment plants, Sustainability, 10(2018)86. https://doi.org/10.3390/su10010086

[15] P. Fernandez-Ibanez, et al., Low cost interventions for disinfection of potable water in developing communities 2019.

[16] B. Langlais, D.A. Reckhow, and D.R. Brink, Ozone in water treatment: application and engineering, Routledge, 2019. https://doi.org/10.1201/9780203744635

[17] A.L. Garner, Pulsed electric field inactivation of microorganisms: from fundamental biophysics to synergistic treatments, Appl. Microbiol. Biotechnol., 103(2019)7917-7929. https://doi.org/10.1007/s00253019-10067-y

[18] P. Vorobev, et al., Deadbands, Droop, and Inertia Impact on Power System Frequency Distribution, IEEE Trans. Power Appar. Syst., 34(2019) 3098-3108. https://doi.org/10.1109/TPWRS.2019.2895547

[19] L. Akter, R. Haque, and M.A. Salam, Comparative evaluation of chromogenic agar medium and conventional culture system for isolation and presumptive identification of uropathogens, Pak. J. Med. Sci., 30(2014) 1033. https://doi.org/10.12669\%2Fpjms.305.5243

[20] G. Schliemann, et al., The diagnosis of urinary tract infection: a systematic review, Dtsch. Arztebl. Int., 107(2010)361. https://doi.org/10.3238/arztebl.2010.0361

[21] G.V. Barbosa, and Q.H. Zhang, Pulsed electric fields in food processing: fundamental aspects and applications, CRC. Press., 2019. https://doi.org/10.1201/9780429133459

[22] M.E. Mohamed, and A.H.A. Eissa, Pulsed electric fields for food processing technology, Structure and function of food engineering, 11(2012) 275-306. https://doi.org/10.5772/48678

[23] F.M. Hassan, and A.R. Mahmood, Evaluate the Efficiency of Drinking Water Treatment Plants in Baghdad City-Iraq, Journal of Applied Environmental Microbiology, 6(2018)1-9. http://dx.doi.org/10.12691/jaem-6$\underline{1-1}$

[24] S. Yasin, A Study of Monthly Changes in some Physical, Chemical, and Phytosanitary parameters in Tigris River at Salah Din Governorate, TJAS., 18(2018) 96-109.

[25] H.M. Selman, A.A.A. Wahid, and G.M. Selman, Evaluating the Performance of Water Treatment Plant (Case Study: Al-Rumaitha Treatment Plant, Al-Muthanna, Iraq), 2015.

[26] N.J. Al-Mansori, Develop and Apply Water Quality Index to Evaluate Water Quality of Shatt-Al-Hilla River, JUBPAS., 25(2017)368-374.

[27] G. Abukhanafer, A.H. Al-Fatlawi, H.H. Joni, Disinfectant filter unit (DFU) in water treatment plant, Test. Eng. Manag., 2020 